\title{
Analysis of Shaft Voltage in a Doubly-fed Induction Generator
}

\author{
Jafar Adabi ${ }^{1}$, Firuz Zare ${ }^{1}$, Arindam Ghosh ${ }^{1}$, Robert D. Lorenz ${ }^{2}$ \\ ${ }^{1}$ School of Electrical Engineering, Queensland University of Technology, GPO Box 2434, Brisbane, QLD, 4001, Australia \\ Email: adabi.jafar@student.qut.edu.au, f.zare@qut.edu.au, a.ghosh@qut.edu.au \\ ${ }^{2}$ University of Wisconsin-Madison, Depts. of ME and ECE, 1513 University Avenue, Madison, WI 53706 \\ Email: lorenz@engr.wisc.edu
}

\begin{abstract}
Fast switching transients and common mode voltage generated by pulse width modulated voltage in high frequency applications may cause many unwanted problems such as shaft voltage and resultant bearing currents. The main objective of this research work is to analyse shaft voltage generation in a doubly-fed induction generator (DFIG) with a back to back converter. A detailed high frequency model of the proposed system has been developed based on capacitive couplings between different objects of the machine. The proposed model can be used for shaft voltage calculations and finding parameters which have key effect on shaft voltage and resultant bearing currents. A discussion about the presented technique for shaft voltage elimination in existing literature is also presented based on mathematical analysis and simulations.
\end{abstract}

\section{Key words}

DFIG, Wind turbine, Shaft voltage, PWM, Common mode voltage

\section{Introduction}

Fig.1 shows a DFIG with a four-quadrant AC-DC-AC converter connected to the rotor windings which enables decoupled control of active and reactive power [1].

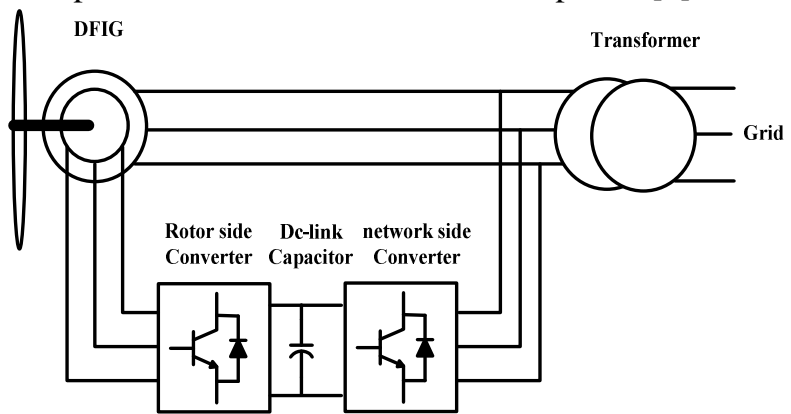

Fig.1. a DFIG with a four-quadrant AC-Dc-AC converter connected to the rotor windings

Power inverters are widely used in wind energy systems to convert $\mathrm{AC}$ output voltage of generators with variable frequency to an adjustable AC voltage for grid connection. On the contrary, there are many parasitic capacitive couplings between different parts of electric machine structure which may be neglected in low frequency analysis but the conditions are completely different in high frequencies. In fast switching converters, a low impedance path is created for the current to flow through these capacitors [2-4]. Due to rapid developments of IGBT technology, switching frequency has dramatically increased. High dv/dt (fast switching transients) and common mode voltage generated by a power inverter in high frequency applications can cause unwanted problems such as: shaft voltage and resultant bearing currents, grounding current escaping to earth through stray capacitors inside a motor, conducted and radiated noises [5-7]. Common mode voltage is known as a potential origin of shaft voltage. Fig. 2 shows a three phase inverter and typical waveforms of three leg voltages and the common mode voltage.

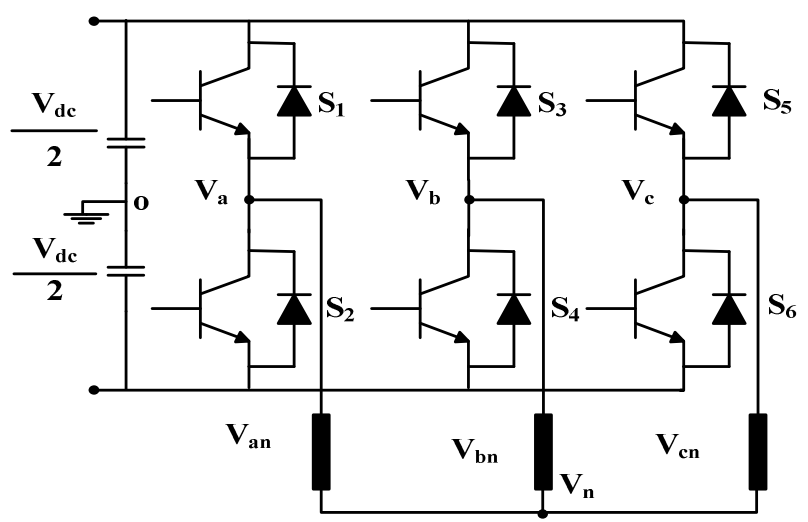

(a)
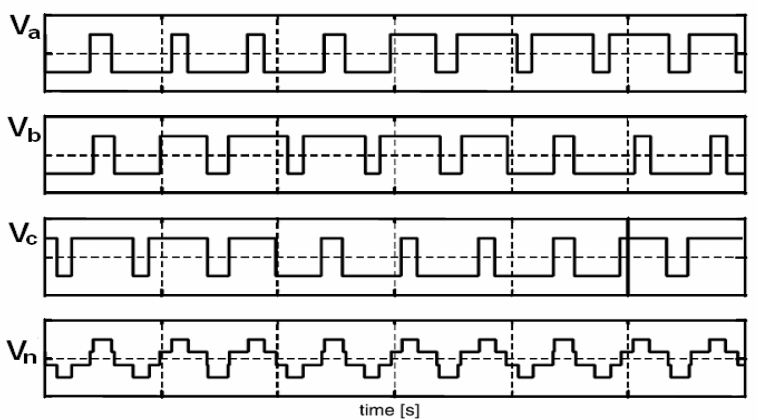

(b)

Fig.2. (a) three phase converter (b) common mode voltage generation 
According to Fig.2.a, three leg voltages of the converter can be calculated as follow:

$\left\{\begin{array}{l}\mathrm{V}_{\mathrm{ao}}(\mathrm{t})=\mathrm{V}_{\mathrm{an}}(\mathrm{t})+\mathrm{V}_{\mathrm{no}}(\mathrm{t}) \\ \mathrm{V}_{\mathrm{bo}}(\mathrm{t})=\mathrm{V}_{\mathrm{bn}}(\mathrm{t})+\mathrm{V}_{\mathrm{no}}(\mathrm{t}) \\ \mathrm{V}_{\mathrm{co}}(\mathrm{t})=\mathrm{V}_{\mathrm{cn}}(\mathrm{t})+\mathrm{V}_{\mathrm{no}}(\mathrm{t})\end{array}\right.$

Where $\left(\mathrm{V}_{\mathrm{ao}}, \mathrm{V}_{\mathrm{bo}}, \mathrm{V}_{\mathrm{co}}\right)$ and $\left(\mathrm{V}_{\mathrm{an}}, \mathrm{V}_{\mathrm{bn}}, \mathrm{V}_{\mathrm{cn}}\right)$ are the leg voltages and phase voltages of a three phase converter, respectively. $\mathrm{V}_{\mathrm{no}}$ is the voltage between neutral point and the ground (common mode voltage). By adding two sides of Eq.1:

$$
\mathrm{V}_{\mathrm{ao}}(\mathrm{t})+\mathrm{V}_{\mathrm{bo}}(\mathrm{t})+\mathrm{V}_{\mathrm{co}}(\mathrm{t})=\mathrm{V}_{\mathrm{an}}(\mathrm{t})+\mathrm{V}_{\mathrm{bn}}(\mathrm{t})+\mathrm{V}_{\mathrm{cn}}(\mathrm{t})+3 \times \mathrm{V}_{\mathrm{no}}(\mathrm{t})
$$

It is obvious that the sum of three phase voltages is equal to zero $\left(\mathrm{V}_{\mathrm{an}}(\mathrm{t})+\mathrm{V}_{\mathrm{bn}}(\mathrm{t})+\mathrm{V}_{\mathrm{cn}}(\mathrm{t})=0\right)$. Therefore, common mode voltage can be calculated as:

$$
\mathrm{V}_{\mathrm{no}}(\mathrm{t})=\frac{\mathrm{V}_{\mathrm{ao}}(\mathrm{t})+\mathrm{V}_{\mathrm{bo}}(\mathrm{t})+\mathrm{V}_{\mathrm{co}}(\mathrm{t})}{3}=\mathrm{V}_{\text {com }}
$$

This equation shows that the common mode voltage is defined by switching pattern. By using appropriate switching pattern, the common mode voltage level can be controlled. Switching states of proposed converter and output voltages and resultant common mode voltage are shown in table. I.

TABLE I. switching states, output leg voltage and common mode voltage of three phase inverter

\begin{tabular}{|c|c|c|c|c|c|c|c|}
\hline vector & $\mathrm{S}_{1}$ & $\mathrm{~S}_{3}$ & $\mathrm{~S}_{5}$ & $\mathrm{~V}_{\mathrm{ac}}$ & $\mathrm{V}_{\mathrm{bo}}$ & $\mathrm{V}_{\mathrm{co}}$ & $\mathrm{V}_{\mathrm{com}}$ \\
\hline $\mathrm{V}_{1}$ & 1 & 0 & 0 & $\frac{\mathrm{V}_{\mathrm{dc}}}{2}$ & $-\frac{\mathrm{V}_{\mathrm{dc}}}{2}$ & $-\frac{\mathrm{V}_{\mathrm{dc}}}{2}$ & $-\frac{\mathrm{V}_{\mathrm{dc}}}{6}$ \\
\hline $\mathrm{V}_{2}$ & 1 & 1 & 0 & $\frac{\mathrm{V}_{\mathrm{dc}}}{2}$ & $\frac{\mathrm{V}_{\mathrm{dc}}}{2}$ & $-\frac{\mathrm{V}_{\mathrm{dc}}}{2}$ & $\frac{\mathrm{V}_{\mathrm{dc}}}{6}$ \\
\hline $\mathrm{V}_{3}$ & 0 & 1 & 0 & $-\frac{\mathrm{V}_{\mathrm{dc}}}{2}$ & $\frac{\mathrm{V}_{\mathrm{dc}}}{2}$ & $-\frac{\mathrm{V}_{\mathrm{dc}}}{2}$ & $-\frac{\mathrm{V}_{\mathrm{dc}}}{6}$ \\
\hline $\mathrm{V}_{4}$ & 0 & 1 & 1 & $-\frac{\mathrm{V}_{\mathrm{dc}}}{2}$ & $\frac{\mathrm{V}_{\mathrm{dc}}}{2}$ & $\frac{\mathrm{V}_{\mathrm{dc}}}{2}$ & $\frac{\mathrm{V}_{\mathrm{dc}}}{6}$ \\
\hline $\mathrm{V}_{5}$ & 0 & 0 & 1 & $-\frac{\mathrm{V}_{\mathrm{dc}}}{2}$ & $-\frac{\mathrm{V}_{\mathrm{dc}}}{2}$ & $\frac{\mathrm{V}_{\mathrm{dc}}}{2}$ & $-\frac{\mathrm{V}_{\mathrm{dc}}}{6}$ \\
\hline $\mathrm{V}_{6}$ & 1 & 0 & 1 & $\frac{\mathrm{V}_{\mathrm{dc}}}{2}$ & $-\frac{\mathrm{V}_{\mathrm{dc}}}{2}$ & $\frac{\mathrm{V}_{\mathrm{dc}}}{2}$ & $\frac{\mathrm{V}_{\mathrm{dc}}}{6}$ \\
\hline $\mathrm{V}_{7}$ & 1 & 1 & 1 & $\frac{\mathrm{V}_{\mathrm{dc}}}{2}$ & $\frac{\mathrm{V}_{\mathrm{dc}}}{2}$ & $\frac{\mathrm{V}_{\mathrm{dc}}}{2}$ & $\frac{\mathrm{V}_{\mathrm{dc}}}{2}$ \\
\hline $\mathrm{V}_{0}$ & 0 & 0 & 0 & $-\frac{\mathrm{V}_{\mathrm{dc}}}{2}$ & $-\frac{\mathrm{V}_{\mathrm{dc}}}{2}$ & $-\frac{\mathrm{V}_{\mathrm{dc}}}{2}$ & $-\frac{\mathrm{V}_{\mathrm{dc}}}{2}$ \\
\hline
\end{tabular}

Recently, some techniques are presented to mitigate shaft voltage and bearing currents in DFIGs. An approach presented in [8] is to constrain the inverter PWM strategy to reduce overall common mode voltages across the rectifier/inverter system, and thus significantly reduce bearing discharge currents. A general common mode model of DFIGs is mentioned in [9] to calculate bearing current.

In this paper, mathematical analysis and simulations have been carried out to find the effective parameters on the shaft voltage of grid-connected induction generators. This paper also presents analysis with an accurate high frequency model of the grid-connected wind generators and voltage sources in high frequencies with simulation results and discussions.

\section{High frequency model of DFIG and shaft voltage calculation}

Fig.3 shows the capacitive couplings in a DFIG and a view of proposed machine structure. Following parasitic capacitive couplings are existed in the proposed machine structure between:

- Stator winding and rotor: $\mathrm{C}_{\mathrm{sr}}$

- Stator winding and stator frame: $\mathrm{C}_{\mathrm{sf}}$

- Stator winding and rotor winding: $\mathrm{C}_{\mathrm{ws}}$

- Stator frame and rotor: $\mathrm{C}_{\mathrm{rf}}$

- Rotor winding and rotor: $\mathrm{C}_{\mathrm{wr}}$

- Rotor winding and Stator frame: $\mathrm{C}_{\mathrm{wf}}$

- Ball bearing, inner and outer races: $\mathrm{C}_{\mathrm{b} 1}, \mathrm{C}_{\mathrm{b} 2}$

As shown in the DFIG structure, a capacitive coupling between the rotor winding and stator winding has a variable value because facing areas of two stator and rotor slots are always changing due to rotor movement.

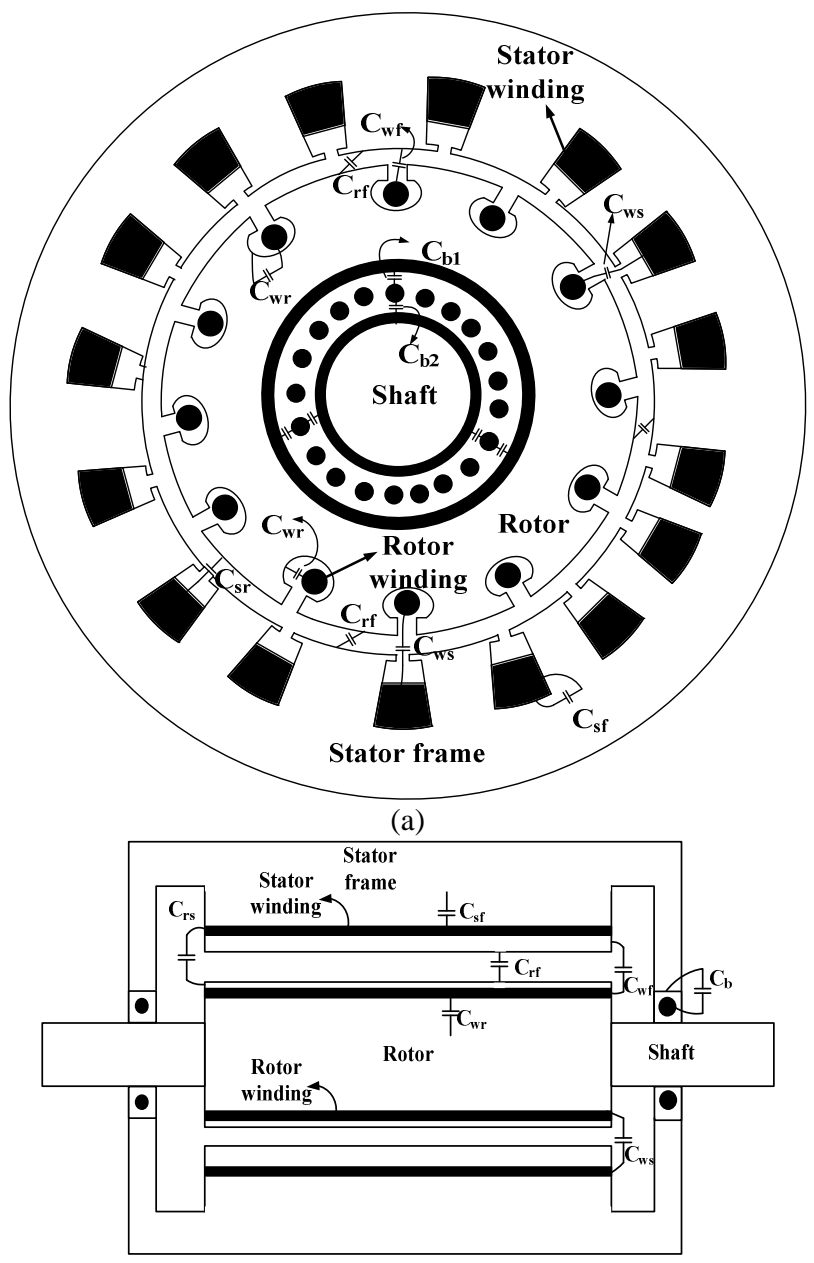

(b)

Fig.3. (a) Capacitance coupling in a doubly fed induction machine and (b) a view of DFIG with different capacitive couplings

Fig. 4 shows the arrangement of a DFIG with a back to back inverter. In this structure, neutral to ground zero sequence voltage of both stator and rotor windings act as common mode voltage sources. The common mode voltage of rotor side and stator side are given as:

$\mathrm{V}_{\mathrm{com}, \mathrm{S}}=\frac{\mathrm{V}_{\mathrm{ao}}+\mathrm{V}_{\mathrm{bo}}+\mathrm{V}_{\mathrm{co}}}{3}$ 
$\mathrm{V}_{\mathrm{com}, \mathrm{R}}=\frac{\mathrm{V}_{\mathrm{xo}}+\mathrm{V}_{\mathrm{yo}}+\mathrm{V}_{\mathrm{zo}}}{3}$

Where $\mathrm{V}_{\mathrm{ao}}, \mathrm{V}_{\mathrm{bo}}, \mathrm{V}_{\mathrm{co}} \& \mathrm{~V}_{\mathrm{xo}}, \mathrm{V}_{\mathrm{yo}}, \mathrm{V}_{\mathrm{zo}}$ are the leg voltages of the converters connected to the stator and rotor, respectively.

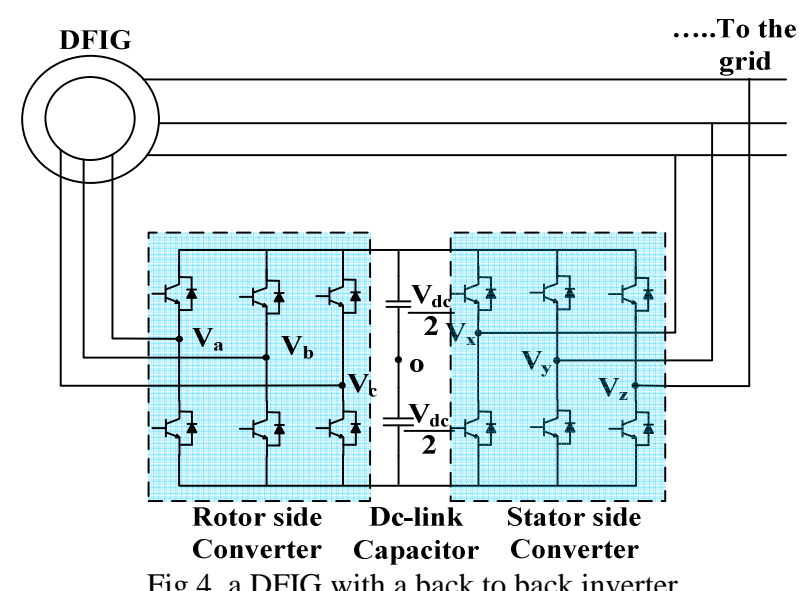

A high frequency model of the proposed doubly fed induction machine is shown in Fig.5.

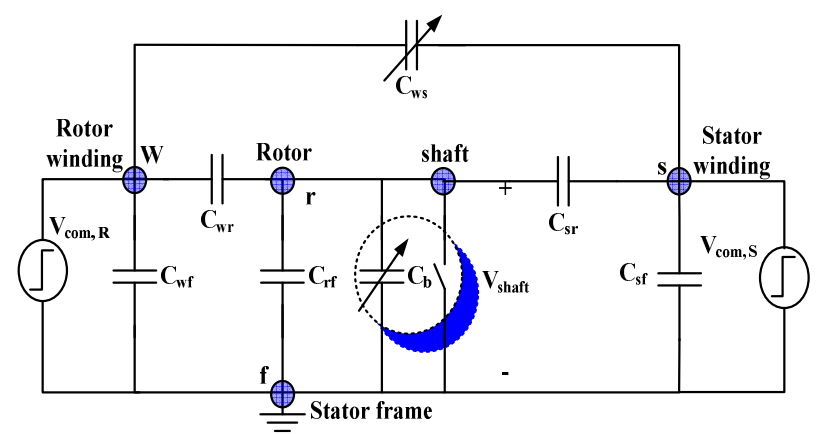

Fig.5. A high frequency model of a doubly fed induction generator

Shaft voltage can be easily calculated by using KCL in the high frequency model of the doubly fed induction generator. According to Fig.5:

$\left(\mathrm{V}_{\text {shaft }}-\mathrm{V}_{\text {comR }}\right) \times \mathrm{C}_{\mathrm{wr}}+\mathrm{V}_{\text {shaft }} \times\left(\mathrm{C}_{\mathrm{rf}}+\mathrm{C}_{\mathrm{b}}\right)+\left(\mathrm{V}_{\text {shaft }}-\mathrm{V}_{\text {coms }}\right) \times \mathrm{C}_{\text {sr }}=0$

So, shaft voltage is:

$$
\begin{aligned}
& \mathrm{V}_{\text {shaft }}=\frac{\mathrm{V}_{\text {com }, \mathrm{R}} \times \mathrm{C}_{\mathrm{wr}}+\mathrm{V}_{\text {com } \mathrm{S}} \times \mathrm{C}_{\mathrm{sr}}}{\mathrm{C}_{\mathrm{wr}}+\mathrm{C}_{\mathrm{rf}}+\mathrm{C}_{\mathrm{b}}+\mathrm{C}_{\mathrm{sr}}} \\
& \mathrm{V}_{\text {shaft }}=\frac{\mathrm{C}_{\mathrm{wr}}}{\mathrm{C}_{\mathrm{wr}}+\mathrm{C}_{\mathrm{rf}}+\mathrm{C}_{\mathrm{b}}+\mathrm{C}_{\mathrm{sr}}} \times \mathrm{V}_{\text {com } \mathrm{R}}+\frac{\mathrm{C}_{\mathrm{sr}}}{\mathrm{C}_{\mathrm{wr}}+\mathrm{C}_{\mathrm{rf}}+\mathrm{C}_{\mathrm{b}}+\mathrm{C}_{\mathrm{sr}}} \times \mathrm{V}_{\text {coms } \mathrm{S}} \\
& \mathrm{V}_{\text {shaft }}=\mathrm{K}_{\mathrm{R}} \times \mathrm{V}_{\text {com }, \mathrm{R}}+\mathrm{K}_{\mathrm{S}} \times \mathrm{V}_{\text {com }, \mathrm{S}}
\end{aligned}
$$

$\mathrm{V}_{\text {com,R }}$ and $\mathrm{V}_{\text {com,S }}$ are the common mode voltage generated by the converters connected to the rotor and the stator windings, respectively. $K_{R}$ and $K_{S}$ are defined as capacitance factors which are effective in total shaft voltage calculation.

$$
\left\{\begin{array}{l}
\mathrm{K}_{\mathrm{R}}=\frac{\mathrm{C}_{\mathrm{wr}}}{\mathrm{C}_{\mathrm{wr}}+\mathrm{C}_{\mathrm{rf}}+\mathrm{C}_{\mathrm{b}}+\mathrm{C}_{\mathrm{sr}}} \\
\mathrm{K}_{\mathrm{S}}=\frac{\mathrm{C}_{\mathrm{sr}}}{\mathrm{C}_{\mathrm{wr}}+\mathrm{C}_{\mathrm{rf}}+\mathrm{C}_{\mathrm{b}}+\mathrm{C}_{\mathrm{sr}}}
\end{array}\right.
$$

By considering $\mathrm{C}_{\mathrm{wr}} \gg \mathrm{C}_{\mathrm{rf}}+\mathrm{C}_{\mathrm{b}}+\mathrm{C}_{\mathrm{sr}}$, the shaft voltage is determined by $\mathrm{C}_{\mathrm{wr}}\left(\mathrm{K}_{\mathrm{R}}\right.$ is almost near 1 and $\mathrm{K}_{\mathrm{S}}$ is a very small value). Fig.6.a shows the simulation results for total shaft voltage. Following values are considered for capacitive couplings: $\mathrm{C}_{\mathrm{wr}}=5 \mathrm{nF}, \mathrm{C}_{\mathrm{rf}}=0.6 \mathrm{nF}, \mathrm{C}_{\mathrm{sr}}=0.3 \mathrm{nF}$, $\mathrm{C}_{\mathrm{b}}=0.1 \mathrm{nF}$.

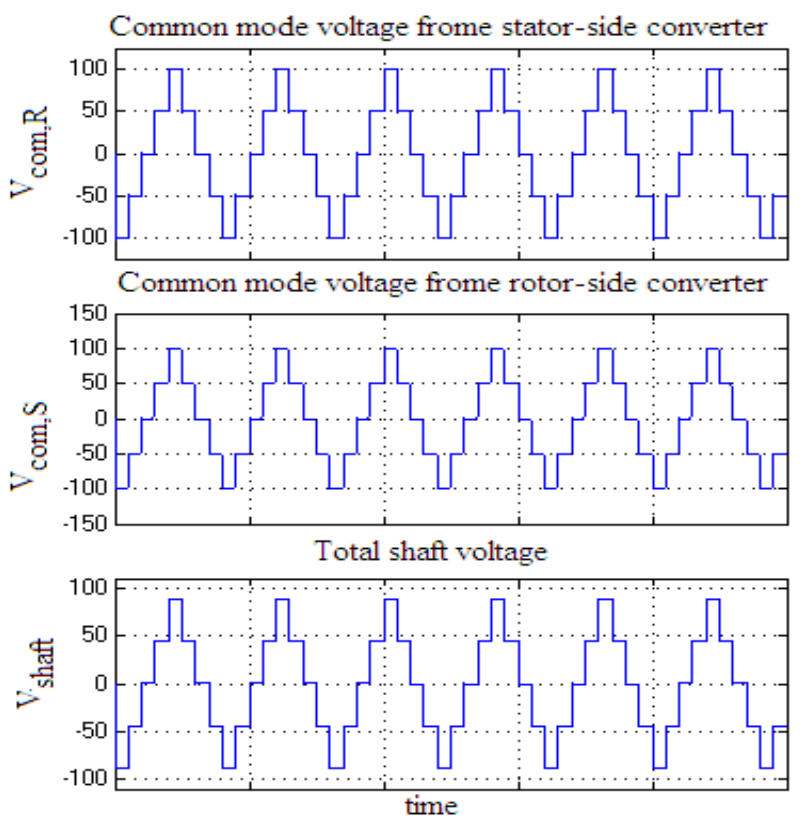

(a)
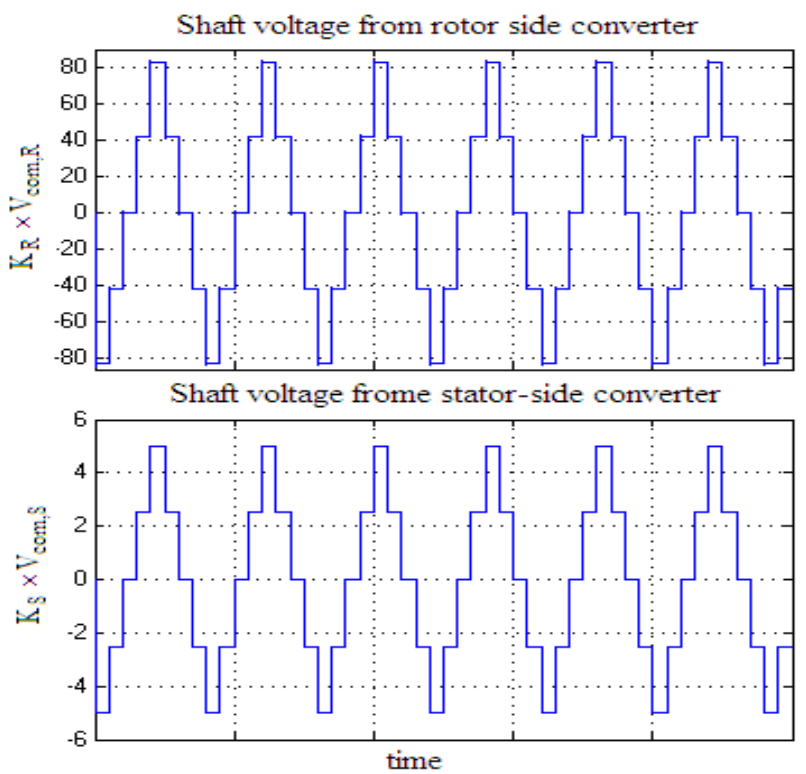

(b)

Fig.6. (a) a typical common mode voltage waveforms and resultant shaft voltage (b) shaft voltage generated by each rotor and stator side converters

Fig.6.b shows the share of each converter in shaft voltage generation. Major portion of the rotor side common mode voltage is transformed to shaft voltage (in this case, $83 \%$ of the rotor side common mode voltage and only $5 \%$ of the stator side common mode voltage). Based on this analysis, the stator common mode voltage has not a key effect on shaft voltage because the capacitive coupling between the stator winding and shaft is too small compare with capacitive coupling between the rotor winding and shaft. 


\section{Discussion}

Analysis of shaft voltage reduction in a DFIG with a back to back inverter was presented in [9] with a pulse width modulation technique to fully remove the shaft voltage based on an equivalent circuit presented in Fig.7.

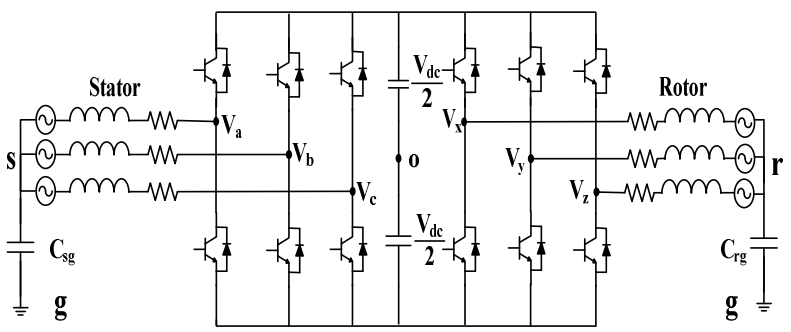

Fig.7. equivalent system of a DFIG system [9]

This arrangement identifies key voltage quantities for purposes of analysis. The capacitance $\mathrm{C}_{\mathrm{sg}}$ represents the capacitance of the stator windings with respect to the stator frame which is assumed to be grounded and $\mathrm{C}_{\mathrm{rg}}$ represents the capacitance between the rotor windings with respect to the stator frame. It can be observed that even though the circuit is grounded, if the voltage potentials of points $\mathrm{s}$ and $\mathrm{r}$ fluctuate in identical fashion then the current flow in the loop containing the ground point $g$ is identically zero so that the ground current can be effectively eliminated if this condition can be reached [9]. Analysis of this circuit shows that the voltage between the two neutral points is:

$\mathrm{V}_{\mathrm{rs}}=\frac{\mathrm{V}_{\mathrm{xr}}+\mathrm{V}_{\mathrm{yr}}+\mathrm{V}_{\mathrm{ys}}}{3}-\frac{\mathrm{V}_{\mathrm{as}}+\mathrm{V}_{\mathrm{bs}}+\mathrm{V}_{\mathrm{cs}}}{3}$

This voltage is called common mode voltage in a DFIG. The presented technique in [9] suggested equalizing of the common mode voltage from rotor and stator side to remove the common mode voltage and as a result the shaft voltage can be considered as zero.

Table II shows the different switching states of a back to back converter considering switching vectors of each converter and resultant common mode voltage.

TABLE II. Different switching states and resultant common

\begin{tabular}{|c|c|c|c|c|c|}
\hline & \multicolumn{4}{|c|}{ mode voltage [9] } \\
\hline & & \multicolumn{4}{|c|}{ Rotor side converter } \\
\hline & & $\begin{array}{c}\text { Vectors } \\
1,3,5\end{array}$ & $\begin{array}{c}\text { Vectors } \\
2,4,6\end{array}$ & $\begin{array}{c}\text { Vector } \\
7\end{array}$ & $\begin{array}{c}\text { Vector } \\
0\end{array}$ \\
\hline \multirow{4}{*}{ 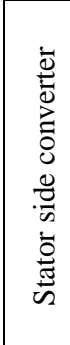 } & $\begin{array}{c}\text { Vectors } \\
1,3,5\end{array}$ & 0 & $\frac{\mathrm{V}_{\mathrm{dc}}}{3}$ & $\frac{2 \mathrm{~V}_{\mathrm{dc}}}{3}$ & 0 \\
\hline & $\begin{array}{c}\text { Vectors } \\
2,4,6\end{array}$ & $\frac{-V_{\mathrm{dc}}}{3}$ & 0 & $\frac{V_{d c}}{3}$ & $\frac{-2 V_{d c}}{3}$ \\
\hline & $\begin{array}{c}\text { Vector } \\
7\end{array}$ & $\frac{-2 V_{\mathrm{dc}}}{3}$ & $\frac{-V_{\mathrm{dc}}}{3}$ & 0 & $-\mathrm{V}_{\mathrm{dc}}$ \\
\hline & $\begin{array}{c}\text { Vector } \\
0\end{array}$ & $\frac{\mathrm{V}_{\mathrm{dc}}}{3}$ & $\frac{2 V_{\mathrm{dc}}}{3}$ & $\mathrm{~V}_{\mathrm{dc}}$ & 0 \\
\hline
\end{tabular}

According to this table, if the switching states of machine side converter and line side converter are both odd, both even or the same zero states from both side converters, the common mode voltage can be forced to zero. In this case, switching vectors $(1,3,5)$ or $(2,4,6)$ are used with and without using zero states.
The main concern is that this technique does not eliminate the shaft voltage and still we have the significant amount of voltage across the shaft which is affected by two sides' voltage sources (neutral points of stator and rotor winding to the ground). In other words, the voltage that is forced to be zero in proposed paper ([9]) is not related to the shaft voltage. This voltage is just the voltage between neutral points of stator winding and rotor winding. Regardless of switching loss, the PWM technique in this paper can not help to mitigate shaft voltage and resultant bearing current. It seems that the capacitive coupling between rotor winding and rotor $\left(\mathrm{C}_{\mathrm{wr}}\right)$ which has a significant effect was not taken into account in the analysis.

To achieve a zero shaft voltage or at least reducing shaft voltage to an appropriate value, both common mode voltage sources should be considered based on an accurate high frequency model of the system. Based on the Eq.8 and Fig.5, it is clear that by choosing a proper rotor common mode voltage (Eq.12), a zero shaft voltage will be achieved.

$\mathrm{V}_{\mathrm{com}, \mathrm{R}}=-\frac{\mathrm{C}_{\mathrm{sr}}}{\mathrm{C}_{\mathrm{wr}}} \times \mathrm{V}_{\mathrm{com}, \mathrm{S}}$

Table III shows the resultant shaft voltage by different switching states of both rotor and stator sides converters. Note that, rotor side common mode voltage has been decreased to $\frac{\mathrm{C}_{\mathrm{sr}}}{\mathrm{C}_{\mathrm{wr}}} \times \mathrm{V}_{\mathrm{com}, \mathrm{S}}$ by a buck converter and shaft voltage is calculated based on Eq.8 and Table I.

TABLE III. Different switching states and shaft voltage

\begin{tabular}{|c|c|c|c|c|c|}
\hline & \multicolumn{4}{|c|}{ Rotor side converter } \\
\hline & & $\begin{array}{c}\text { Vectors } \\
1,3,5 \\
\end{array}$ & $\begin{array}{c}\text { Vectors } \\
2,4,6 \\
\end{array}$ & $\begin{array}{c}\text { Vector } \\
7 \\
\end{array}$ & $\begin{array}{c}\text { Vector } \\
0 \\
\end{array}$ \\
\hline \multirow{4}{*}{ 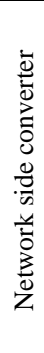 } & $\begin{array}{c}\text { Vectors } \\
1,3,5\end{array}$ & $\frac{-\mathrm{K}_{\mathrm{S}} \mathrm{V}_{\mathrm{dc}}}{3}$ & 0 & $\frac{\mathrm{K}_{\mathrm{S}} \mathrm{V}_{\mathrm{dc}}}{3}$ & $\frac{-2 \mathrm{~K}_{\mathrm{S}} \mathrm{V}_{\mathrm{dc}}}{3}$ \\
\hline & $\begin{array}{c}\text { Vectors } \\
2,4,6\end{array}$ & 0 & $\frac{\mathrm{K}_{\mathrm{S}} \mathrm{V}_{\mathrm{dc}}}{3}$ & $\frac{2 \mathrm{~K}_{\mathrm{S}} \mathrm{V}_{\mathrm{dc}}}{3}$ & $\frac{-\mathrm{K}_{\mathrm{S}} \mathrm{V}_{\mathrm{dc}}}{3}$ \\
\hline & $\begin{array}{c}\text { Vector } \\
7\end{array}$ & $\frac{\mathrm{K}_{\mathrm{S}} \mathrm{V}_{\mathrm{dc}}}{3}$ & $\frac{2 \mathrm{~K}_{\mathrm{S}} \mathrm{V}_{\mathrm{dc}}}{3}$ & $\mathrm{~K}_{\mathrm{S}} \mathrm{V}_{\mathrm{dc}}$ & 0 \\
\hline & $\begin{array}{c}\text { Vector } \\
0\end{array}$ & $\frac{-2 \mathrm{~K}_{\mathrm{S}} \mathrm{V}_{\mathrm{dc}}}{3}$ & $\frac{-\mathrm{K}_{\mathrm{S}} \mathrm{V}_{\mathrm{dc}}}{3}$ & 0 & $-\mathrm{K}_{\mathrm{S}} \mathrm{V}_{\mathrm{dc}}$ \\
\hline
\end{tabular}

To eliminate the shaft voltage completely, the condition of Eq.12 should be applied in the analysis. To meet these requirements, it is needed to apply odd switching vectors $(1,3$, and 5$)$ to one converter and even switching vectors $\left(2,4\right.$, and 6) to another converter. Also, switching $\mathrm{V}_{0}$ from one side and $\mathrm{V}_{7}$ from other side is conducted to generate zero shaft voltage. As it can be seen from this table, the results in table III is completely different to table II. Fig. 8 shows a typical common mode voltage from rotor side, common mode voltage from stator side and resultant shaft voltage based on proposed switching pattern. In this case, rotor side voltage is decreased based on the ratio of $\mathrm{C}_{\mathrm{wr}}$ and $\mathrm{C}_{\mathrm{sr}}$ and the shaft voltage is forced to be zero. From the analysis, it is obvious that rotor side converter is playing key role in shaft voltage generation of a DFIG structure. 

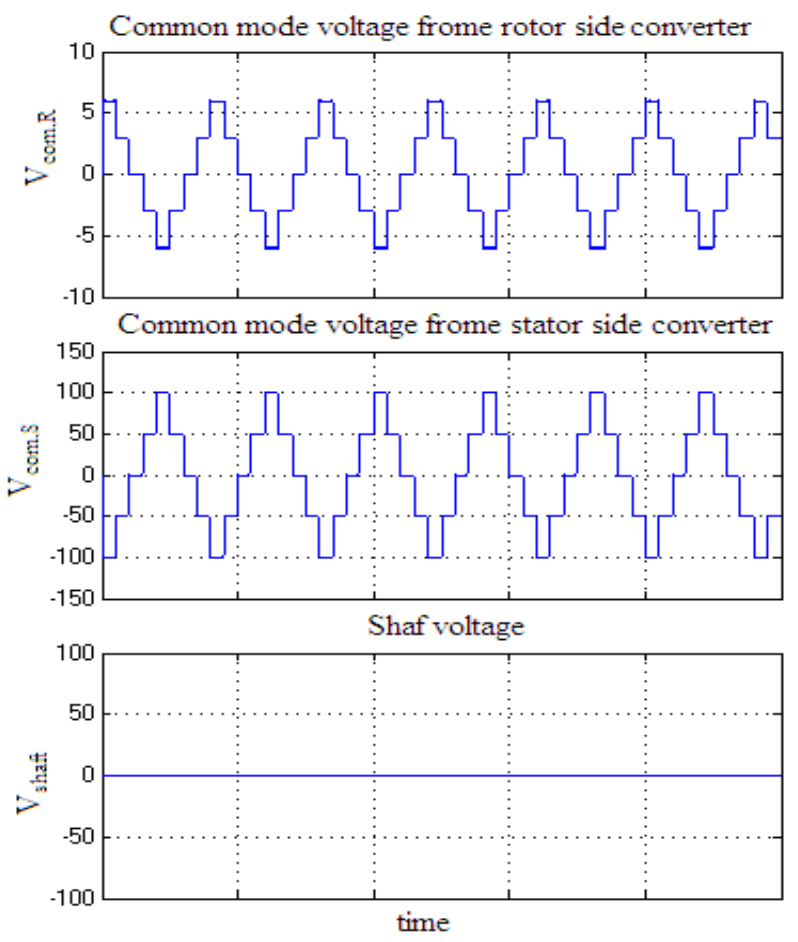

Fig.8. a typical common mode voltage waveforms and zero shaft voltage

The presented PWM pattern can be used as an effective technique to reduce the shaft voltage. One of the issues regarding to this technique is that, a bidirectional buck converter should be employed to reduce the dc-link voltage $\left(\mathrm{V}_{\mathrm{c} 1}\right)$ by the ratio of $\frac{\mathrm{C}_{\mathrm{sr}}}{\mathrm{C}_{\mathrm{wr}}}$ to create a rotor side common mode voltage equal to $\frac{\mathrm{C}_{\mathrm{sr}}}{\mathrm{C}_{\mathrm{wr}}} \times \mathrm{V}_{\mathrm{com}, \mathrm{S}}$ (see Fig.9).

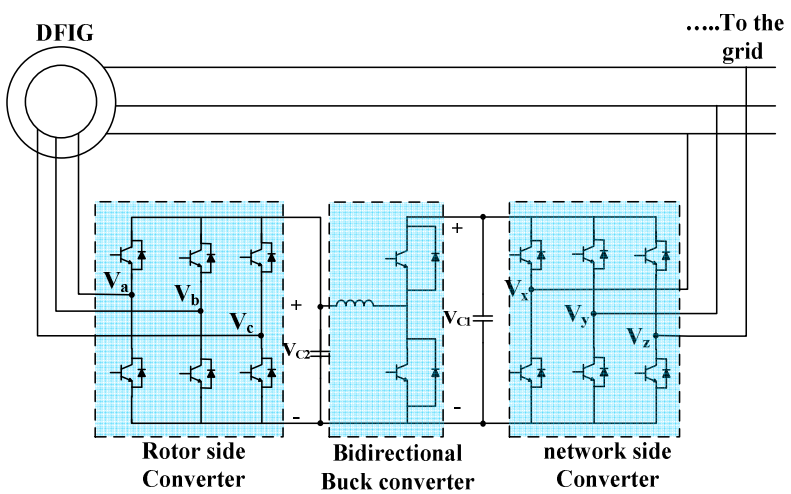

Fig.9. a new back-to-back inverters topology with a bidirectional buck converter and a DFIG

In this configuration, the limitation of the duty cycle of the buck converter should be considered. These conditions may affect the dynamic performance of the DFIG. Therefore, cancellation of the shaft voltage based on this topology should be mentioned in terms of practical barriers and dynamic analysis of the system which is beyond the scope of this paper.

\section{Conclusions}

In this paper, an accurate high frequency model of a DFIG has been presented to analyse mitigation techniques of the shaft voltage. Proposed model is based on the capacitive couplings between different parts of the generator structure and the common mode voltage source. Mathematical equations which define the shaft voltage based on capacitive couplings between rotor and stator frames and their windings have been presented. According to the analysis, the most important capacitive coupling in a doubly fed induction generator is the capacitive coupling between the rotor winding and the rotor frame. A PWM technique has been presented in literature to remove the overall common mode voltage in a DFIG but the above mentioned analysis shows that this technique can not help to eliminate the shaft voltage. Mathematical analysis and simulation results have been presented to verify the investigations.

\section{Acknowledgement}

The authors thank the Australian Research Council (ARC) for the financial support for this project through the ARC Discovery Grant DP0774497.

\section{References}

[1] S.Muller, M.Deicke, R.W.De Doncker, Doubly fed induction generator systems for wind turbines, Industry Applications Magazine, IEEE, vol. 8, pp. 26 -33, May. 2002.

[2] J. M. Erdman, R. J. Kerkman, D. W. Schlegel, and G. L. Skibinski, "Effect of PWM inverters on AC motor bearing currents and shaft voltages," Industry Applications, IEEE Transactions on, vol. 32, pp. 250-259, 1996.

[3] C. Mei, J. C. Balda, W. P. Waite, and K. Carr, "Minimization and cancellation of common-mode currents, shaft voltages and bearing currents for induction motor drives," presented at Power Electronics Specialist Conference, 2003. PESC '03, IEEE 34th Annual, 2003.

[4] Jafar Adabi, Firuz Zare, Gerard Ledwich, Arindam Ghosh, "Leakage Current and Common Mode Voltage Issues in Modern AC Drive Systems", presented at AUPEC 2007, Perth, Australia, Dec 2007.

[5] Firuz Zare, "Modelling of Electric Motors for Electromagnetic Compatibility Analysis", presented at AUPEC 2006, Melbourne, Australia, Nov 2006.

[6] M. M. Swamy, K. Yamada, and T. Kume, "Common mode current attenuation techniques for use with PWM drives," Power Electronics, IEEE Transactions on, vol. 16, pp. 248-255, 2001.

[7] S. Chen, T. A. Lipo, and D. Fitzgerald, "Source of induction motor bearing currents caused by PWM inverters" Energy Conversion, IEEE Transaction on, vol. 11, pp. 25-32, 1996.

[8] Johann Zitzelsberger, Wilfried Hofmann, Andreas Wiese, "Bearing Currents in Doubly-Fed Induction Generators", Power Electronics and Applications, 2005 European Conference on, 11-14 Sept. 2005

[9] A.M.Garcia, D.G. Holmes, T.A. Lipo, ," Reduction of Bearing Currents in Doubly Fed Induction Generators" Industry Applications Conference, 2006. 41st IAS Annual Meeting, Conference Record of the 2006 IEEE, Volume 1, on page(s): 84-89 